\title{
Some Parameters Affecting the Behavior of Strengthening of Rectangular R.C. Beams Failed in Shear by Using C.F.R.P.
}

\author{
Assem Nan SaleebKaldes ${ }^{1}$, Prof. Dr. Abd El-Rahman Megahid Ahmed ${ }^{2}$, Prof. Dr. Mohammed \\ M. M. Rashwan' ${ }^{2}$ Prof. Dr. Mohamed M. Ahmed ${ }^{3}$ \\ ${ }^{I}$ Master of Science, Department of Civil Engineering Faculty of Engineering, Assiut University \\ ${ }^{2}$ Professor of Properties and Strength of Materials, Assuit University \\ ${ }^{3}$ Associated Professor of Structural Engineering, Assuit University, Egypt
}

\begin{abstract}
*Corresponding Author: Dr. Assem Nan Saleeb Kaldes, Master of Science, Department of Civil Engineering Faculty of Engineering, Assiut University, Egypt.
\end{abstract}

\begin{abstract}
This paper exemplifies both the shear strengthening capacity and modes of failure of Reinforced Concrete $(R C)$ rectangular shear beams bonded externally with carbon fiber reinforced polymer CFRP-U strips. Sixteen $R C$ beams without internal shear reinforcement and four beams with internal shear reinforcement were tested; seven beams were kept as a control beams; whereas other beams were strengthened externally with CFRP-U strips. Test variables were (i)grade of concrete (ii) longitudinal tensile reinforcement ratio (iii) \% of shear reinforcement (iv) orientation of CFRP strips ( $v$ )width of CFRP strips (vi) spacing of CFRP strips. Tests results show the effectiveness and shear capacity of CFRP strengthened specimens. The shear enhancement of CFRP strengthened beams varied between $17 \%$ and $127 \%$ over the control beams depending on various factors. This study confirms that the CFRP-U strips technique significantly enhances the shear capacity of reinforced concrete shear beams. The experimental results of the shear-CFRP strengthened beam were compared with the available theoretical results.
\end{abstract}

\section{INTRODUCTION}

Strengthening of Reinforced Concrete (RC) structural members using externally bonded Fiber Reinforced polymer (FRP) fabrics have been attracted by many researchers. The demand to use the FRP fabrics or sheets is due to its better characteristics than other conventional materials. The major characteristics include high strength to weight ratio, high stiffness, light weight, flexibility and resistance to corrosion. Moreover, there are several other advantages attributed to their use including ease of bonding to curved or any irregular surfaces, easy to install on site without any special equipment, minimal traffic interruption, and less time consumption. In recent years, the exploitation of fiber reinforced polymer composites as external reinforcement is an evergreen technique of improving the structural performance of reinforced concrete structures.

Literature review reported that the flexural strengthening behaviour of reinforced concrete beams has been abundantly addressed. In fact the flexural strengthening mechanism of reinforced concrete beams was studied well but not complicated like shear mechanism. Shear failure of reinforced concrete beam is catastrophic and could occur suddenly without any advance forewarning. Many of existing RC beams have been found to be deficient in shear strength and need to be strengthened. Several factors need to be considered in shear deficient structure such as lack of shear reinforcement or reduction in steel area due to corrosion, increased service load than design, construction faults and old design codes. The CFRP strip technique is more economical compared to continuous wrapping system.

\section{OBJECTIVES OF THIS STUDY}

The overall objective of this investigation was to study both the shear strengthening capacity and modes of failure of reinforced concrete rectangular shear beams bonded externally with Carbon Fiber Reinforced Polymer (CFRP) strips under static loading. Specific objectives are as follows: 
Some Parameters Affecting the Behavior of Strengthening of Rectangular R.C. Beams Failed in Shear by Using C.F.R.P.

-Investigating the effectiveness of the CFRP strip technique on strengthening full-scale reinforced concrete rectangular beams without any internal shear reinforcement (i.e. no steel stirrups).

- Investigating how the factors such as (i) grade of concrete (ii) longitudinal tensile reinforcement ratio (iii) \% of shear reinforcement (iv) orientation of CFRP strips (v) width of CFRP strips (vi) spacing of CFRP strips influence the shear capacity of the strengthened reinforced concrete beams.

-Comparing the shear capacity of CFRP strengthened beams with the available theoretical results.

\section{EXPERIMENTAL PROGRAM}

\subsection{Tests spacimens}

The test program includes twenty reinforced concrete beams. All tested beams having the same total length of $1500 \mathrm{~mm}$ and cross section of $120 \mathrm{~mm}$ width and $300 \mathrm{~mm}$ depth. The steel reinforcement of all beams was, four bars $16 \mathrm{~mm}$ diameter as tension reinforcement, two bars $10 \mathrm{~mm}$ diameter as compression reinforcement without any internal shear reinforcement, additionally to four beams with 8mm dia.@100mm and 300mm as internal shear reinforcement, details of reinforcement are as shown in figs.1.Shear span to effective depth ratio for all beams was kept constant $\left(a_{v} / d=1.67\right)$.

All beams were tested under two point of static load placed at $500 \mathrm{~mm}$ from the ends of two supports. Table 1and Fig.1 give summary of testing program and specimens details. The parameters investigated in this study included (i) grade of concrete (ii) longitudinal tensile reinforcement ratio (iii) $\%$ of shear reinforcement (iv) orientation of CFRP strips( $\beta$ ) (v) width of CFRP strips $\left(\mathrm{W}_{\mathrm{f}}\right)$ (vi) spacing of CFRP strips $\left(\mathrm{S}_{\mathrm{f}}\right)$.

Table1: Specimens details

\begin{tabular}{|c|c|c|c|c|c|c|c|}
\hline \multirow[t]{2}{*}{ Group } & \multirow{2}{*}{$\begin{array}{l}\text { Beam } \\
\text { No. }\end{array}$} & \multirow{2}{*}{$\begin{array}{c}\text { Grade of } \\
\text { Concrete } \\
\mathrm{Fc}_{28} \\
\mathrm{~kg} / \mathrm{cm} 2\end{array}$} & \multirow{2}{*}{$\begin{array}{l}\text { longitudinal } \\
\text { tensile } \\
\text { reinforceme- } \\
\text { nt ratio }(\mu \%)\end{array}$} & \multirow{2}{*}{$\begin{array}{l}\% \text { of shear } \\
\text { reinforcement } \\
\text { ratio }\end{array}$} & \multicolumn{3}{|c|}{ Configuration of external strengthening } \\
\hline & & & & & $\begin{array}{c}\text { orientation } \\
\text { of CFRP } \\
\text { strips }(\beta)\end{array}$ & $\begin{array}{l}\text { width of } \\
\text { CFRP } \\
\text { strips } \\
\mathrm{W}_{\mathrm{f}}\end{array}$ & $\begin{array}{c}\text { spacing of } \\
\text { CFRP } \\
\text { strips } \\
S_{\mathrm{f}}\end{array}$ \\
\hline \multirow[t]{6}{*}{ Group(I) } & R1a & C250 & $2.22 \%$ & zero & ------ & ------ & ------ \\
\hline & R2 & C500 & $2.22 \%$ & zero & ------- & ------ & ------- \\
\hline & R3 & C700 & $2.22 \%$ & zero & ------- & ------ & ------- \\
\hline & B1a & $\mathrm{C} 250$ & $2.22 \%$ & zero & $90^{\circ}$ & $60 \mathrm{~mm}$ & $135 \mathrm{~mm}$ \\
\hline & B2 & $\mathrm{C} 500$ & $2.22 \%$ & zero & $90^{\circ}$ & $60 \mathrm{~mm}$ & $135 \mathrm{~mm}$ \\
\hline & B3 & $\mathrm{C} 700$ & $2.22 \%$ & zero & $90^{\circ}$ & $60 \mathrm{~mm}$ & $135 \mathrm{~mm}$ \\
\hline \multirow[t]{4}{*}{ Group(II) } & $\mathrm{R} 4$ & $\mathrm{C} 250$ & $0.62 \%$ & zero & $\begin{array}{l}------ \\
-9\end{array}$ & $\begin{array}{ll}----- \\
\end{array}$ & $\begin{array}{c}------ \\
\end{array}$ \\
\hline & R5 & $\mathrm{C} 250$ & $1.11 \%$ & zero & $\begin{array}{l}----- \\
-1\end{array}$ & $\begin{array}{ll}----- \\
\end{array}$ & $\begin{array}{ll}----- \\
\end{array}$ \\
\hline & B4 & $\mathrm{C} 250$ & $0.62 \%$ & zero & $90^{\circ}$ & $60 \mathrm{~mm}$ & $135 \mathrm{~mm}$ \\
\hline & B5 & $\mathrm{C} 250$ & $1.11 \%$ & zero & $90^{\circ}$ & $60 \mathrm{~mm}$ & $135 \mathrm{~mm}$ \\
\hline \multirow[t]{4}{*}{ Group(III) } & R6 & $\mathrm{C} 250$ & $2.22 \%$ & $\begin{array}{c}8 \mathrm{~mm} \\
\text { dia.@300mm }\end{array}$ & ------- & ------ & ------ \\
\hline & R7 & $\mathrm{C} 250$ & $2.22 \%$ & $\begin{array}{c}8 \mathrm{~mm} \\
\text { dia.@100mm }\end{array}$ & ------- & ------ & ------- \\
\hline & B6 & $\mathrm{C} 250$ & $2.22 \%$ & $\begin{array}{c}8 \mathrm{~mm} \\
\text { dia. } @ 250 \mathrm{~mm} \\
\end{array}$ & $90^{\circ}$ & $60 \mathrm{~mm}$ & $135 \mathrm{~mm}$ \\
\hline & B7 & $\mathrm{C} 250$ & $2.22 \%$ & $\begin{array}{c}8 \mathrm{~mm} \\
\text { dia. } @ 100 \mathrm{~mm}\end{array}$ & $90^{\circ}$ & $60 \mathrm{~mm}$ & $135 \mathrm{~mm}$ \\
\hline \multirow[t]{6}{*}{ Group(IV) } & B8 & $\mathrm{C} 250$ & $2.22 \%$ & zero & $45^{\circ}$ & $60 \mathrm{~mm}$ & $135 \mathrm{~mm}$ \\
\hline & B9 & $\mathrm{C} 250$ & $2.22 \%$ & zero & $60^{\circ}$ & $60 \mathrm{~mm}$ & $135 \mathrm{~mm}$ \\
\hline & B10 & $\mathrm{C} 250$ & $2.22 \%$ & zero & $90^{\circ}$ & $90 \mathrm{~mm}$ & $135 \mathrm{~mm}$ \\
\hline & B11 & $\mathrm{C} 250$ & $2.22 \%$ & zero & $90^{\circ}$ & $45 \mathrm{~mm}$ & $135 \mathrm{~mm}$ \\
\hline & B12 & $\mathrm{C} 250$ & $2.22 \%$ & zero & $90^{\circ}$ & $60 \mathrm{~mm}$ & $180 \mathrm{~mm}$ \\
\hline & B13 & $\mathrm{C} 250$ & $2.22 \%$ & zero & $90^{\circ}$ & $60 \mathrm{~mm}$ & $100 \mathrm{~mm}$ \\
\hline
\end{tabular}




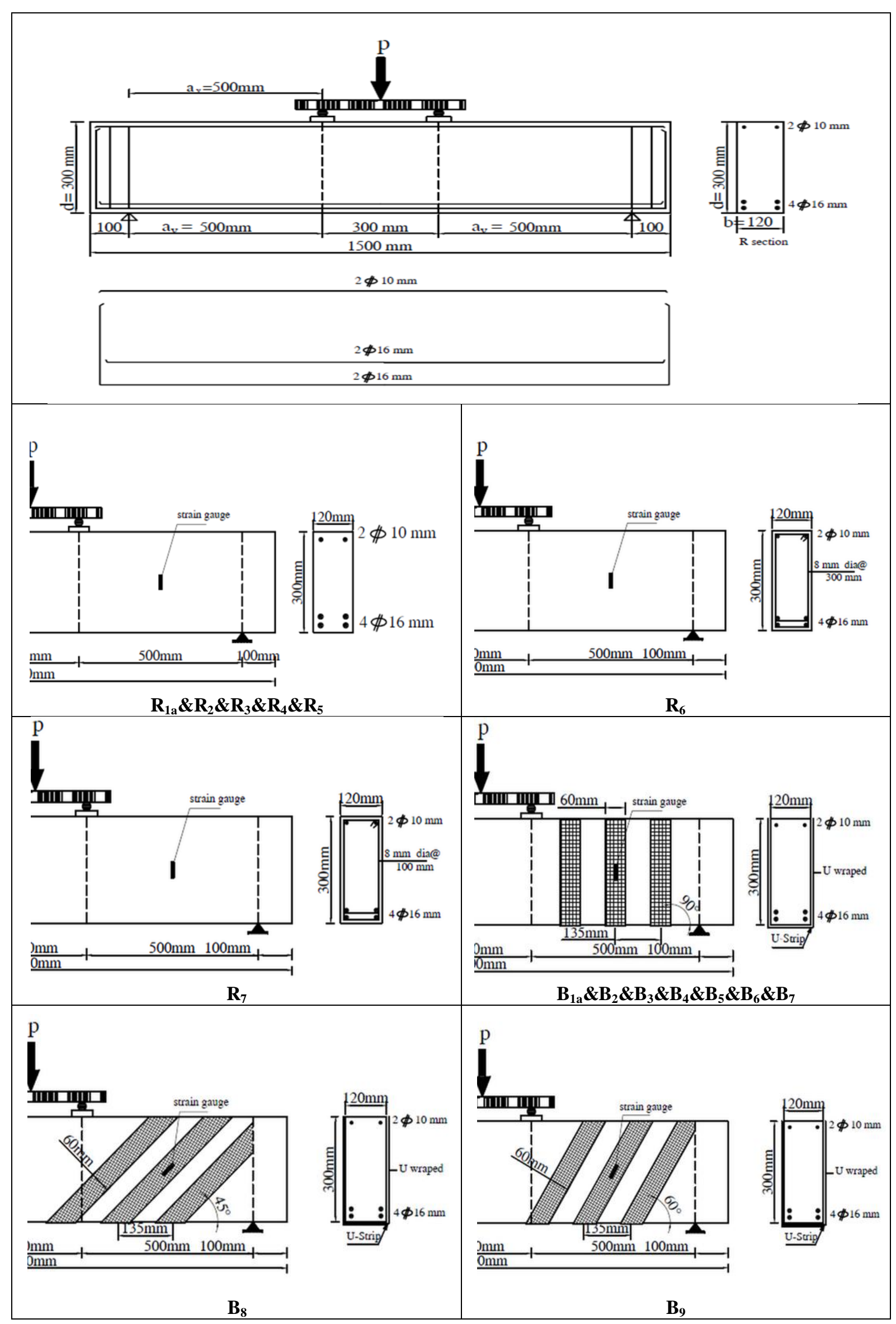




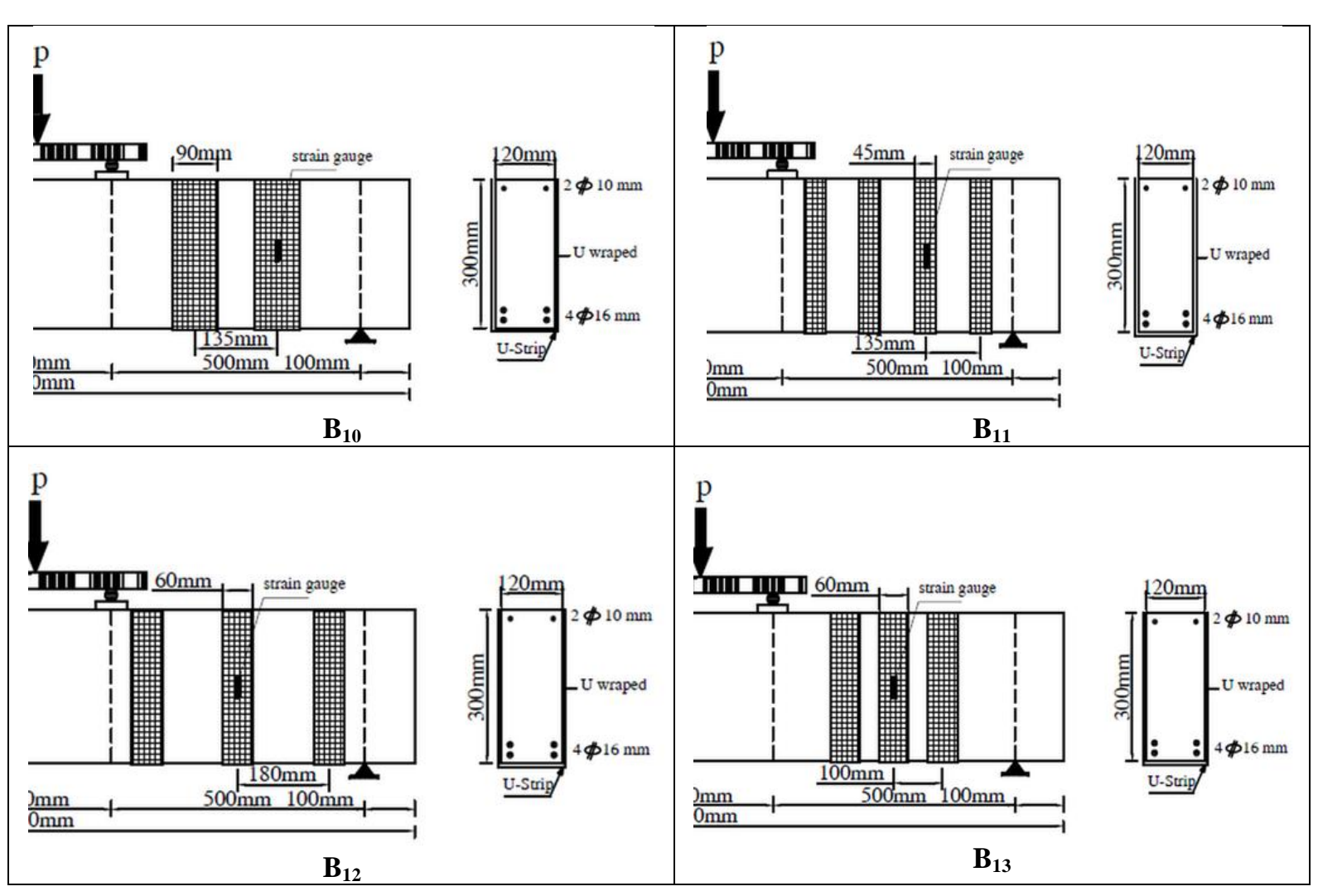

Fig1. Details of test specimens

\subsection{Materials}

\subsubsection{Used Materials for Concrete Mixes}

- Cement: Ordinary Portland cement(O.P.C.

- Sand: the used sand had a specific gravity, volume weight and fineness modulus of $2.6,1.6 \mathrm{t} / \mathrm{m}^{3}$ and 2.95, respectively.

- Gravel: the used gravel was $20 \mathrm{mms}$ maximum nominal size , and had specific gravity and volume weight of 2.65 and $1.65 \mathrm{t} / \mathrm{m}^{3}$ respectively.

- Bazalt: the used Bazalt was $20 \mathrm{mms}$ maximum nominal size, and had specific gravity and volume weight of 2.65 and $1.65 \mathrm{t} / \mathrm{m}^{3}$ respectively.

- Admixture: 1- silicafum

\section{2- sikament F.F.3}

- Water: natural drinking water.

\subsubsection{Concrete Mixes}

The constituent materials for a mix of $1 \mathrm{~m}^{3}$ concrete by weight for each grade of concrete $\left(\mathrm{Fc}_{28}\right) \mathrm{kg}$. $/ \mathrm{cm}^{2}$ is as given below:

\begin{tabular}{|c|c|c|c|c|c|c|}
\hline \multirow{2}{*}{$\begin{array}{c}\text { Grade of } \\
\text { concrete } \\
\mathrm{Fc}_{28} \\
\left(15^{*} 15^{*} 15\right) \\
\mathrm{Kg} / \mathrm{cm}^{2}\end{array}$} & \multicolumn{5}{|c|}{ Constituent materials for $1 \mathrm{~m}^{3}$ mix by weight $(\mathrm{Kg})$} & \multirow[t]{2}{*}{ Water litre } \\
\hline & Cement & $\begin{array}{c}\text { Fine } \\
\text { aggregate } \\
\text { (sand) }\end{array}$ & $\begin{array}{c}\text { Coarse } \\
\text { aggregate }\end{array}$ & Silicafume & $\begin{array}{c}\text { Sikament } \\
\text { F.F.3 }\end{array}$ & \\
\hline 250 & 350 & 550 & 1290 (gravel) & -------- & -------- & 192 \\
\hline 500 & 450 & 550 & 1200 (bazalt) & 100 & 14 & 145 \\
\hline 700 & 550 & 500 & 1200 (bazaltt) & 110 & 16 & 145 \\
\hline
\end{tabular}

\subsubsection{Steel Reinforcement}

The used steel bars for stirrups were mild steel type with diameter $\left(8 \mathrm{~mm}\right.$ ) of $3100 \mathrm{k.g} . / \mathrm{cm}^{2}$ yield strength, and for the compression and tension reinforcement were high tensile steel type with diameters $(10 \mathrm{~mm}, 16 \mathrm{~mm})$ of 3900 and $4100 \mathrm{k.g} . / \mathrm{cm}^{2}$ proof strength respectively. 
Some Parameters Affecting the Behavior of Strengthening of Rectangular R.C. Beams Failed in Shear by Using C.F.R.P.

\subsubsection{External Bonded CFRP Strip}

Uniaxial Carbon Fiber Reinforced polymer (CFRP) wraps were used to externally strengthen the shear spans of the beam, under a commercial name of sikawrap. Hex-230C. CFRP is available in rolled of $0.12 \mathrm{~mm}$ effective thickness, $300 \mathrm{~mm}$ width, and about $5000 \mathrm{~mm}$ length. According to the data provided by the CFRP supplier, the fabrics had an elastic modulus of $210000 \mathrm{~N} / \mathrm{mm}^{2}$, tensile (rupture) strength $2400 \mathrm{~N} / \mathrm{mm}^{2}$, and ultimate strain of $1.7 \%$.

\subsubsection{Adhesive Material}

The adhesive material used in the test program with the CFRP strip is (Sikadur-330) consists of two components with ratio $1: 3$. The tensile strength at 10 days age was found to be $0.32 \mathrm{t} / \mathrm{cm} 2$. With (sikadur-41/31) used as epoxy mortar and primer.

\subsection{Application of CFRP}

Surfaces of the beam to be strengthened were roughened using a grinder, and the edges of the beam where the CFRP U- jackets were applied has been rounded in curved shape of about $30 \mathrm{~mm}$ diameter to reduce the stress concentration generated on the composite at the beam edges. After that, the concrete surfaces were cleaned by compressed air. An epoxy mortar (sikadur-41) of about $2.0 \mathrm{~mm}$ thickness was applied to bonding surfaces as substratum to the CFRP sheets, but before that a primer coat (sikadur-31) was applied first on the bonding surface to promote the adhesion between the concrete surface and the applied epoxy mortar. After about 24 hours a two-part epoxy adhesive (sikadur-330) was applied in a thin layer over the epoxy mortar and the precut CFRP sheets were placed over it. The sheets were pressed firmly and rolled uniformly by a roller to squeeze out excess epoxy and all air bubbles.

\subsection{Test procedure}

All beams were tested under two-points loading over a span of $1300 \mathrm{~mm}$. The load was applied to the beams in increments. At each increment, the mid-span deflection, and the strains in middle height of some of CFRP U strips were measured by means of dial and electrical strain gauges. The crack initiation and propagation were monitored by visual inspection during testing.

\section{Test Results}

\begin{tabular}{|c|c|c|c|c|c|c|c|c|c|c|}
\hline $\begin{array}{c}\text { BEAM } \\
\text { NO. }\end{array}$ & $\begin{array}{l}\mathbf{P}_{\text {crack }} \\
\text { (ton) }\end{array}$ & $\begin{array}{c}\mathbf{P}_{\text {ulitma- }} \\
\text { te } \\
\text { (ton) }\end{array}$ & Max. $\varepsilon_{\mathrm{c}}$ & Max. $\varepsilon_{\text {c.f. }}$ & $\operatorname{Max} . \varepsilon_{\mathrm{s}}$ & $\begin{array}{c}\text { Max. } \\
\boldsymbol{\delta}_{\boldsymbol{u}} \\
\mathrm{mm} \\
\text { Mid } \\
\text { span }\end{array}$ & $\begin{array}{l}\boldsymbol{\delta}_{\boldsymbol{c r}} \\
\mathrm{mm}\end{array}$ & $\begin{array}{c}\begin{array}{c}\text { Ductili- } \\
\text { ty }\end{array} \\
\frac{\delta_{u}}{\delta_{c r}} \%\end{array}$ & $\begin{array}{c}\text { Tough- } \\
\text { ness } \\
\text { (Area } \\
\text { under } \\
\text { load-def. } \\
\text { curve) } \\
\text { mm.t. }\end{array}$ & $\begin{array}{c}\text { Mode } \\
\text { of } \\
\text { failure }\end{array}$ \\
\hline R1a & 6.60 & 12.00 & 0.00022 & ------- & 0.00075 & 3.53 & 1.36 & 259.5 & 22.15 & shear \\
\hline B1a & 11.50 & 24.00 & ------ & 0.00007 & 0.00011 & 4.62 & 3.15 & 146.7 & 56.47 & shear \\
\hline $\mathbf{R 2}$ & 13.50 & 24.00 & 0.00117 & ------ & 0.00041 & 5.25 & 2.20 & 238.6 & 62.6 & shear \\
\hline B2 & 16.50 & 36.00 & ------- & 0.00022 & 0.00009 & 6.80 & 3.55 & 191.5 & 140.3 & shear \\
\hline R3 & 14.50 & 32.00 & 0.00193 & ------- & 0.00084 & 5.73 & 2.08 & 275.5 & 63.9 & shear \\
\hline B3 & 17.00 & 40.50 & ------- & 0.00010 & 0.00051 & 7.20 & 3.8 & 189.5 & 193.7 & shear \\
\hline R4 & 5.00 & 10.50 & 0.00010 & ------ & 0.00076 & 2.87 & 1.34 & 214.2 & 18.3 & shear \\
\hline B4 & 7.40 & 14.00 & ------- & 0.00015 & 0.00101 & 3.83 & 1.91 & 200.5 & 32.13 & shear \\
\hline R5 & 5.40 & 11.50 & 0.00037 & ------- & 0.00031 & 4.05 & 1.51 & 268.2 & 13.2 & shear \\
\hline B5 & 8.20 & 20.00 & ------- & 0.00128 & 0.00032 & 5.30 & 2.30 & 230.4 & 39 & shear \\
\hline R6 & 8.20 & 22.50 & 0.00068 & ------- & .00015 & 4.81 & 1.45 & 331.7 & 62.8 & shear \\
\hline B6 & 12.50 & 31.50 & --.---- & 0.00011 & $\begin{array}{l}0.00030 \\
\end{array}$ & 5.84 & 2.35 & 248.5 & 90.9 & shear \\
\hline R7 & 9.40 & 27.50 & .000086 & ------- & 0.00014 & 4.72 & 1.74 & 271.3 & 61.7 & shear \\
\hline B7 & 13.50 & 33.50 & ------- & 0.00029 & 0.00011 & 8.22 & 3.42 & 240.4 & 148.8 & shear \\
\hline B8 & 15.00 & 27.00 & ------- & 0.00011 & 0.00133 & 4.82 & 2.75 & 175.3 & 71.1 & shear \\
\hline B9 & 13.00 & 25.50 & -.---.- & 0.00035 & 0.00013 & 5.53 & 2.62 & 211.1 & 57.8 & shear \\
\hline B10 & 12.00 & 21.5 & ------- & 0.00023 & 0.00085 & 4.53 & 2.30 & 196.95 & 55.2 & shear \\
\hline B11 & 10.50 & 19.5 & ------- & 0.00013 & 0.00012 & 4.45 & 2.15 & 206.9 & 47.3 & shear \\
\hline B12 & 10.00 & 21.50 & ------ & 0.00017 & 0.00041 & 4.52 & 2.21 & 204.5 & 55.5 & shear \\
\hline B13 & 10.50 & 23.00 & ------- & 0.00007 & 0.00089 & 4.24 & 2.45 & 173.1 & 51.8 & shear \\
\hline
\end{tabular}




\subsection{W.R.T Failure Modes}

In general, and as expected all test specimens failed mainly as a result of diagonal tension cracking (shear failure). Cracking pattern at ultimate load and failure modes of all beams are shown in Fig.2. Each specimen exhibited an initial flexural crack in the region of pure bending and subsequent additional flexural cracks formed in the central region. As applied load was increased a number of flexural and shear cracks were developed along the shear spans and one of them extended diagonally upward toward the loading point. Failure of controlled beams $\left(R_{1 a} \& R_{2} \& R_{3} \& R_{4} \& R_{5} \& R_{6} \& R_{7}\right)$ were sudden and by diagonal tension. In case of strengthened beams, the diagonal tension failure was preceded by CFRP strips bond failure and /or CFRP rupture, and the diagonal cracks occurred at a relatively higher load than for the control beam. All strengthened beams failed by concrete splitting and crushing behind the fiber strips. The splitting of concrete behind the strips caused these fiber strips to be ruptured or pushed out wards (debonding).

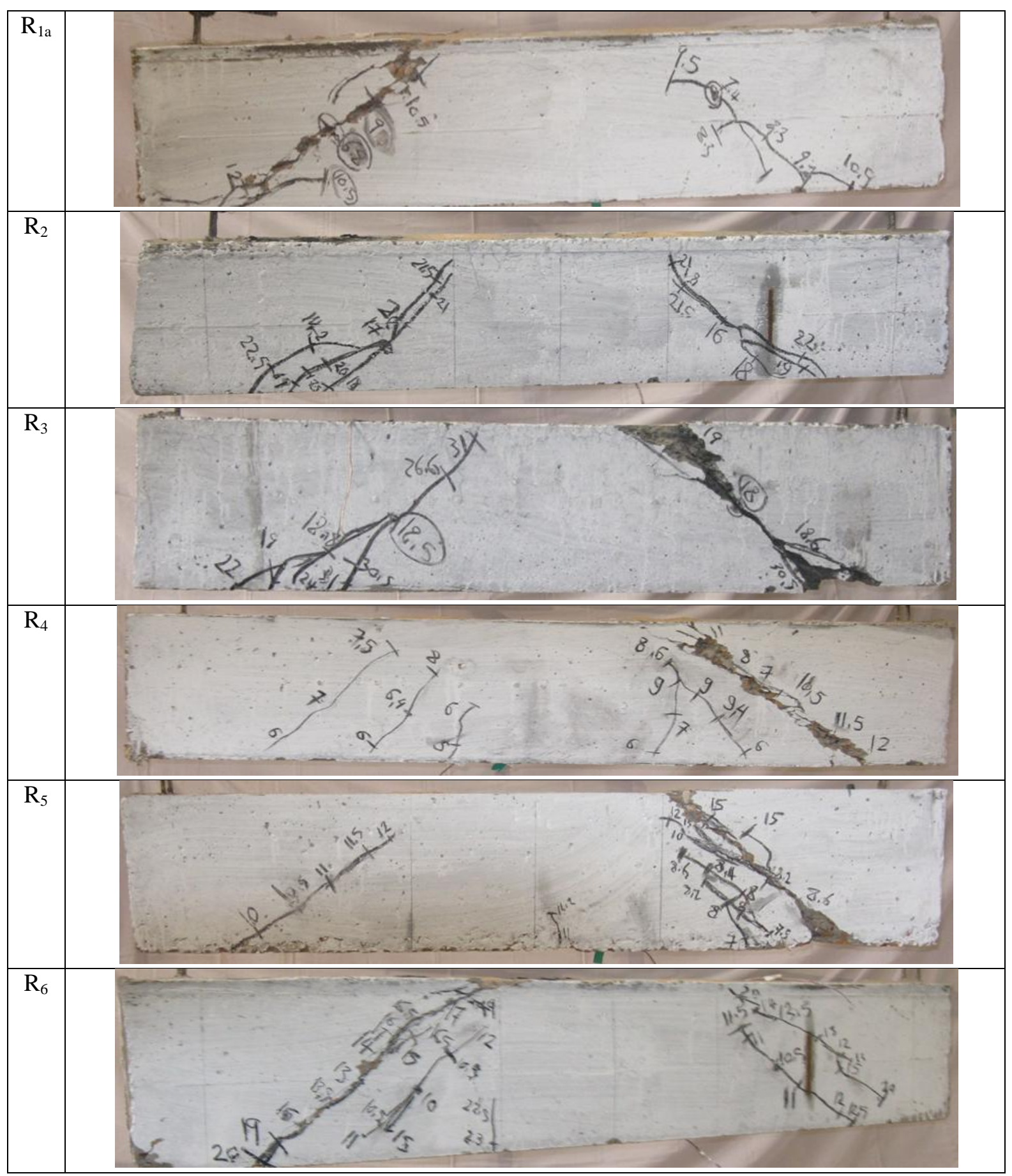


Some Parameters Affecting the Behavior of Strengthening of Rectangular R.C. Beams Failed in Shear by Using C.F.R.P.

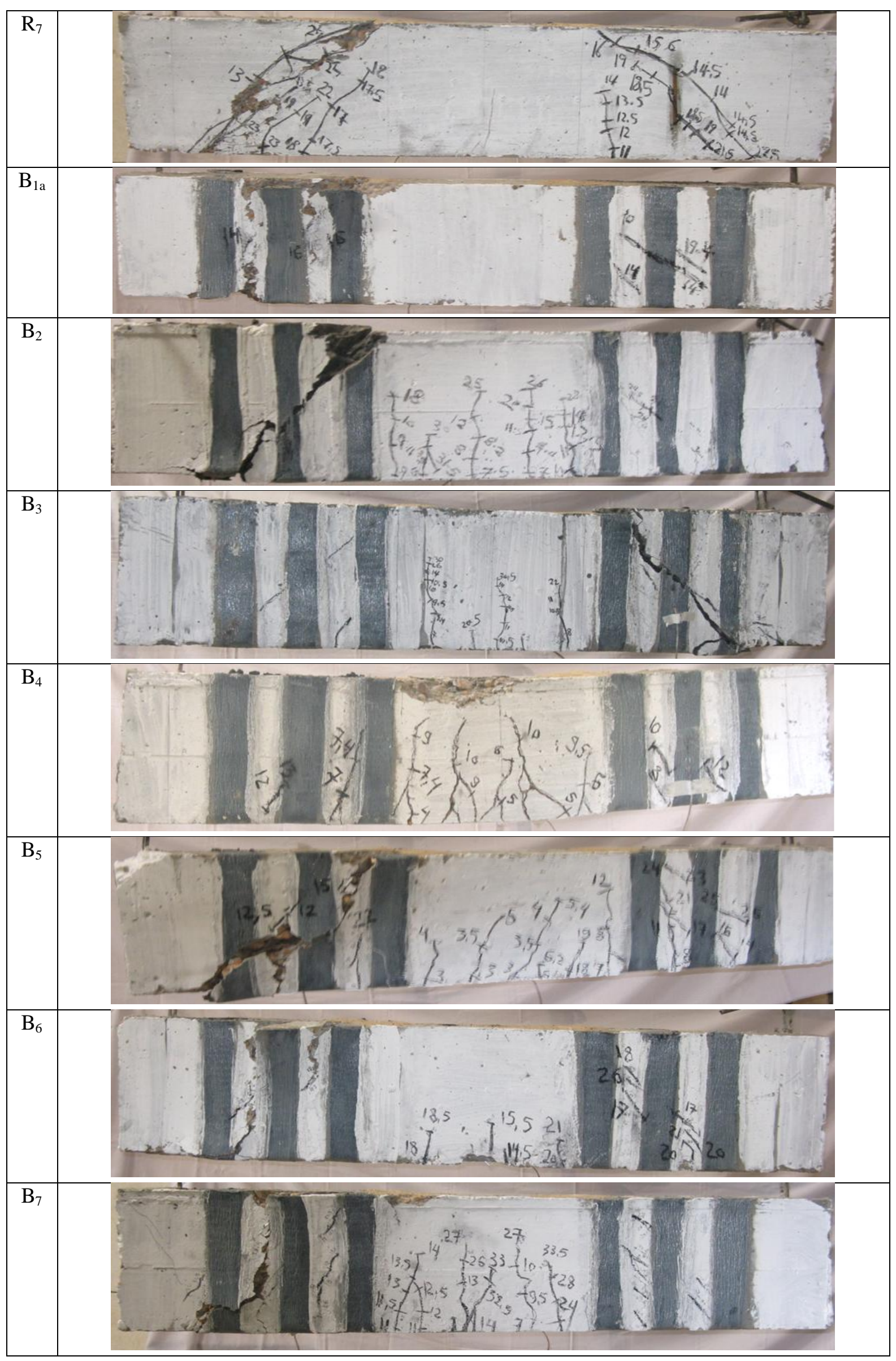


Some Parameters Affecting the Behavior of Strengthening of Rectangular R.C. Beams Failed in Shear by Using C.F.R.P.

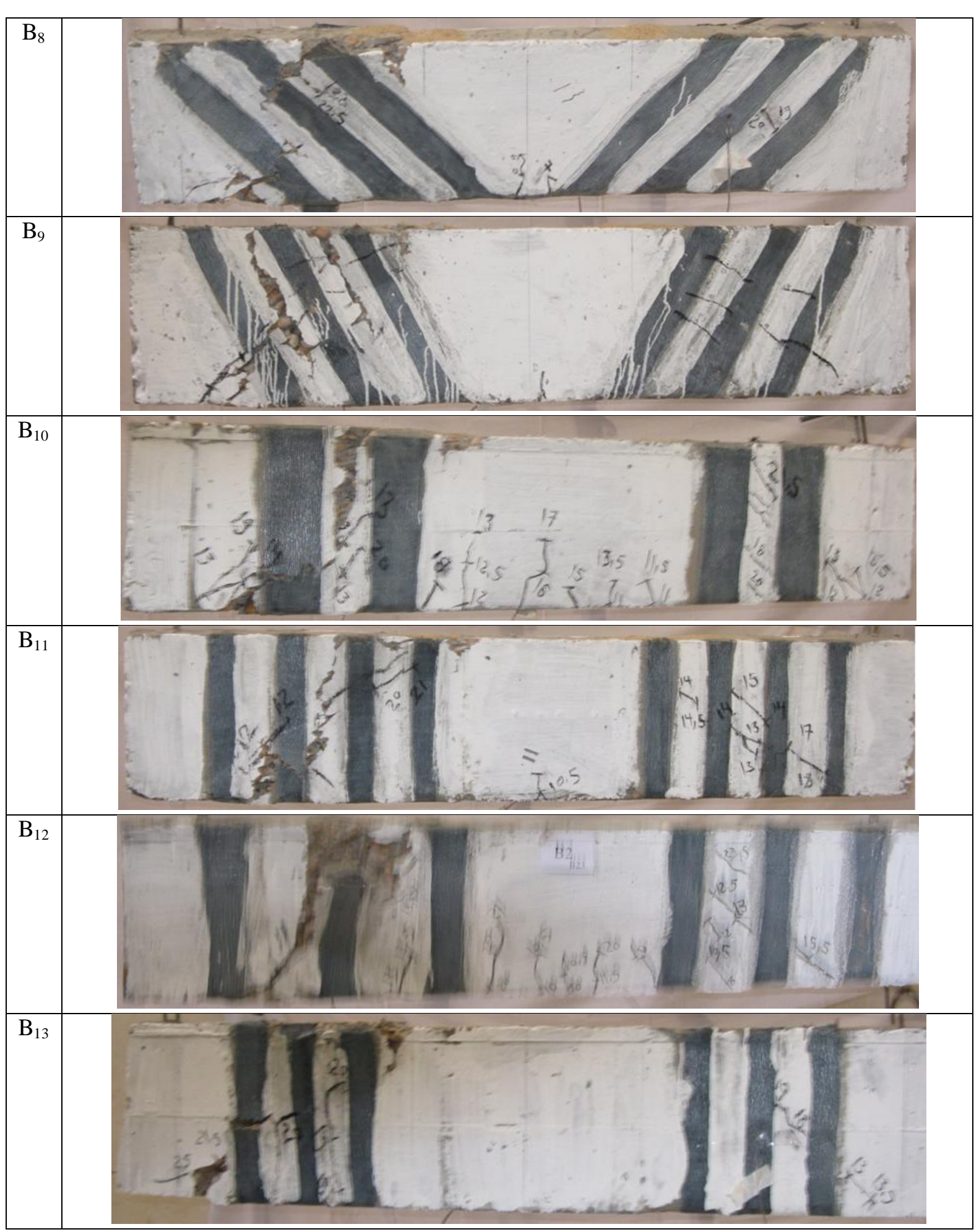

Fig2: Crack patterns of tested beams

\subsection{W.R.T Load-Deflection Curves}

Load-mid-span deflection curves for all specimens are shown in Fig.3. It can be noticed that, the initial slope of all curves identical. This means that the provided external shear reinforcement ( Ustrips) did not increase the initial flexural stiffness of beam, but has a signification effect on both ultimate load and ductility. Fig.3show that grade of concrete, longitudinal tensile reinforcement ratio, $\%$ of shear reinforcement, orientation of CFRP strips, width of CFRP strips and spacing of CFRP strips influence the shear capacity of the strengthened reinforced concrete beams. 
Some Parameters Affecting the Behavior of Strengthening of Rectangular R.C. Beams Failed in Shear by Using C.F.R.P.
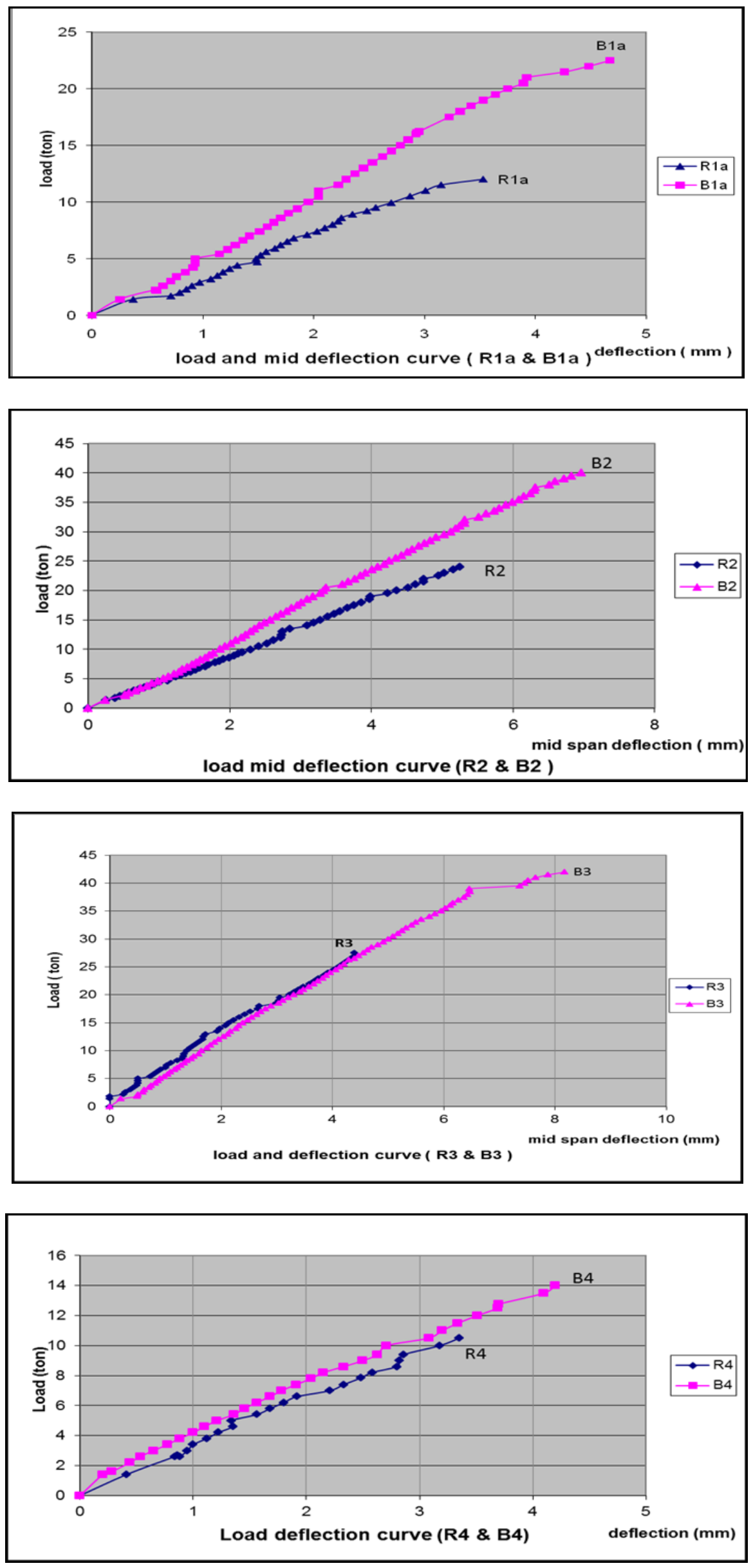
Some Parameters Affecting the Behavior of Strengthening of Rectangular R.C. Beams Failed in Shear by Using C.F.R.P.
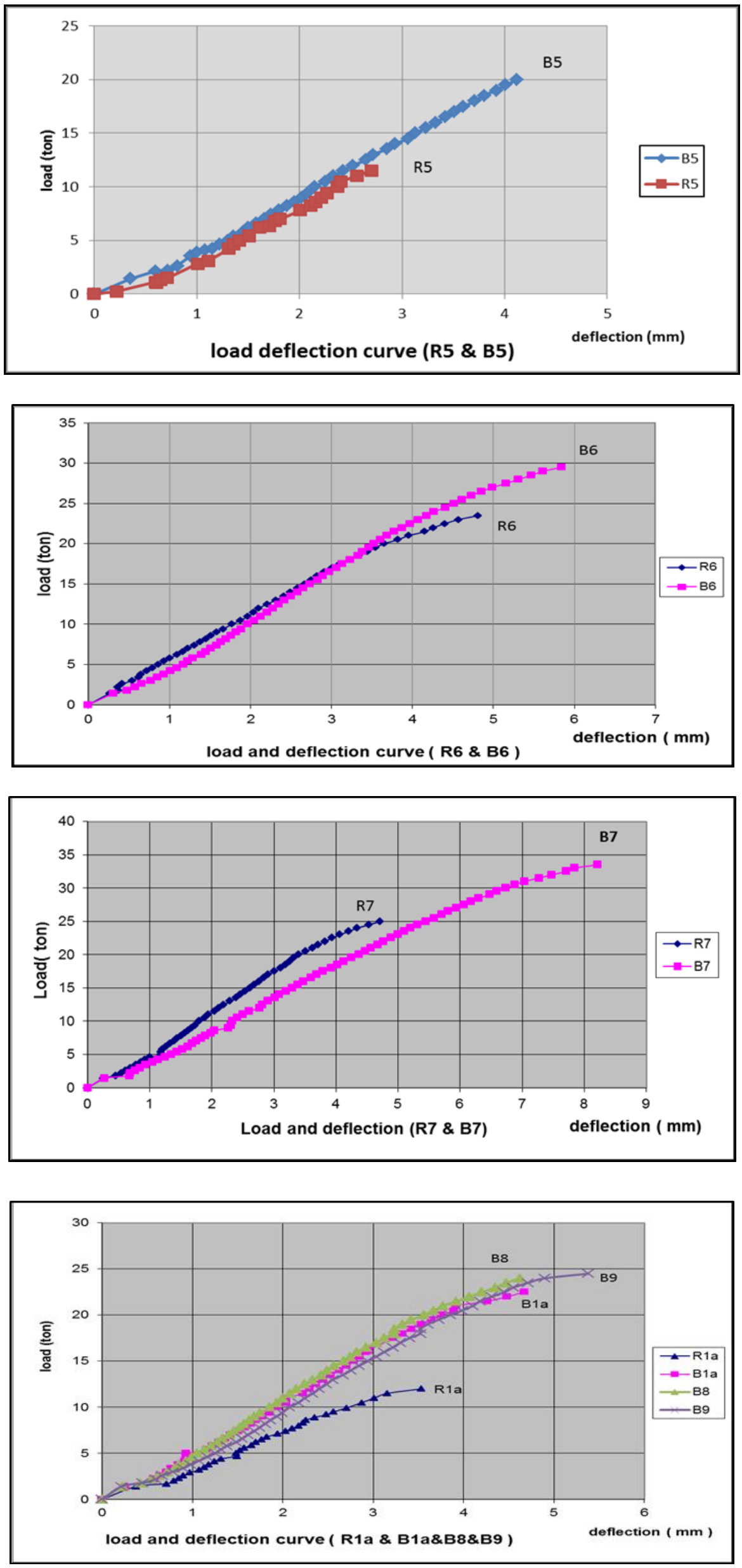

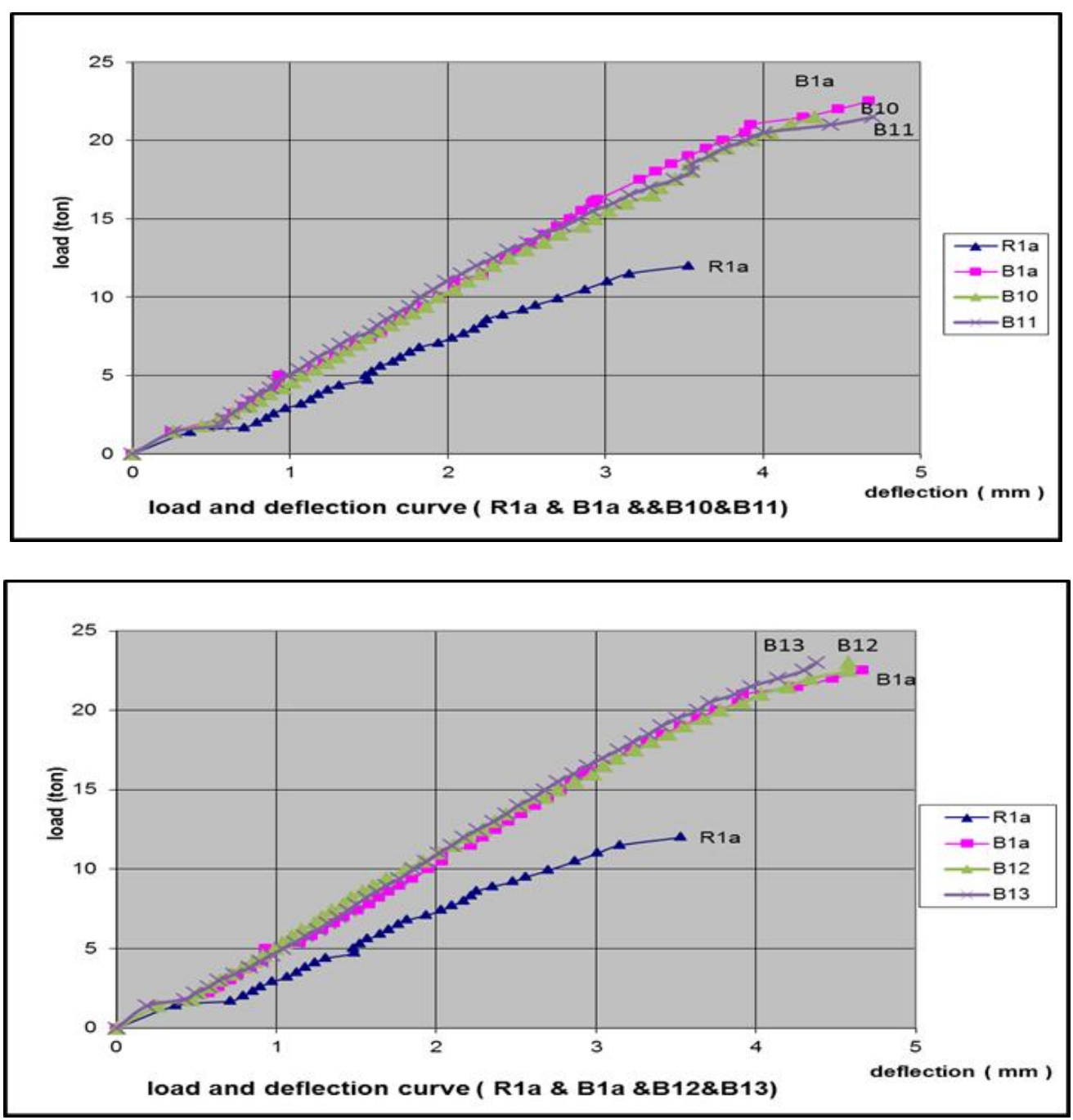

Fig3. Load and mid-deflection curve for test beams

\subsection{W.R.T Load -CFRP Strainscurves}

Fig.4shows that the load versus vertical strain in carbon fiber sheet at mid-depth of sheet at a certain locations (see Fig.1). also the maximum strain $\left(\varepsilon_{\max }\right)$ recorded in these strips just before failure of beams :

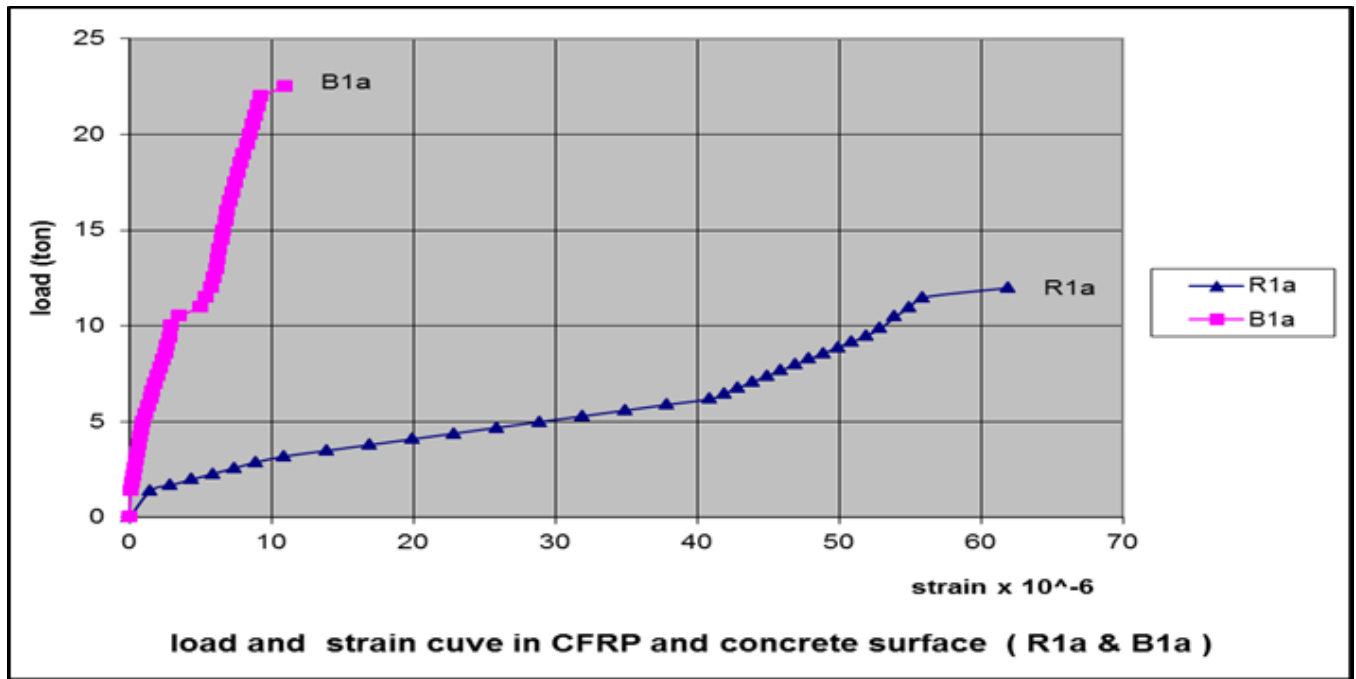


Some Parameters Affecting the Behavior of Strengthening of Rectangular R.C. Beams Failed in Shear by Using C.F.R.P.
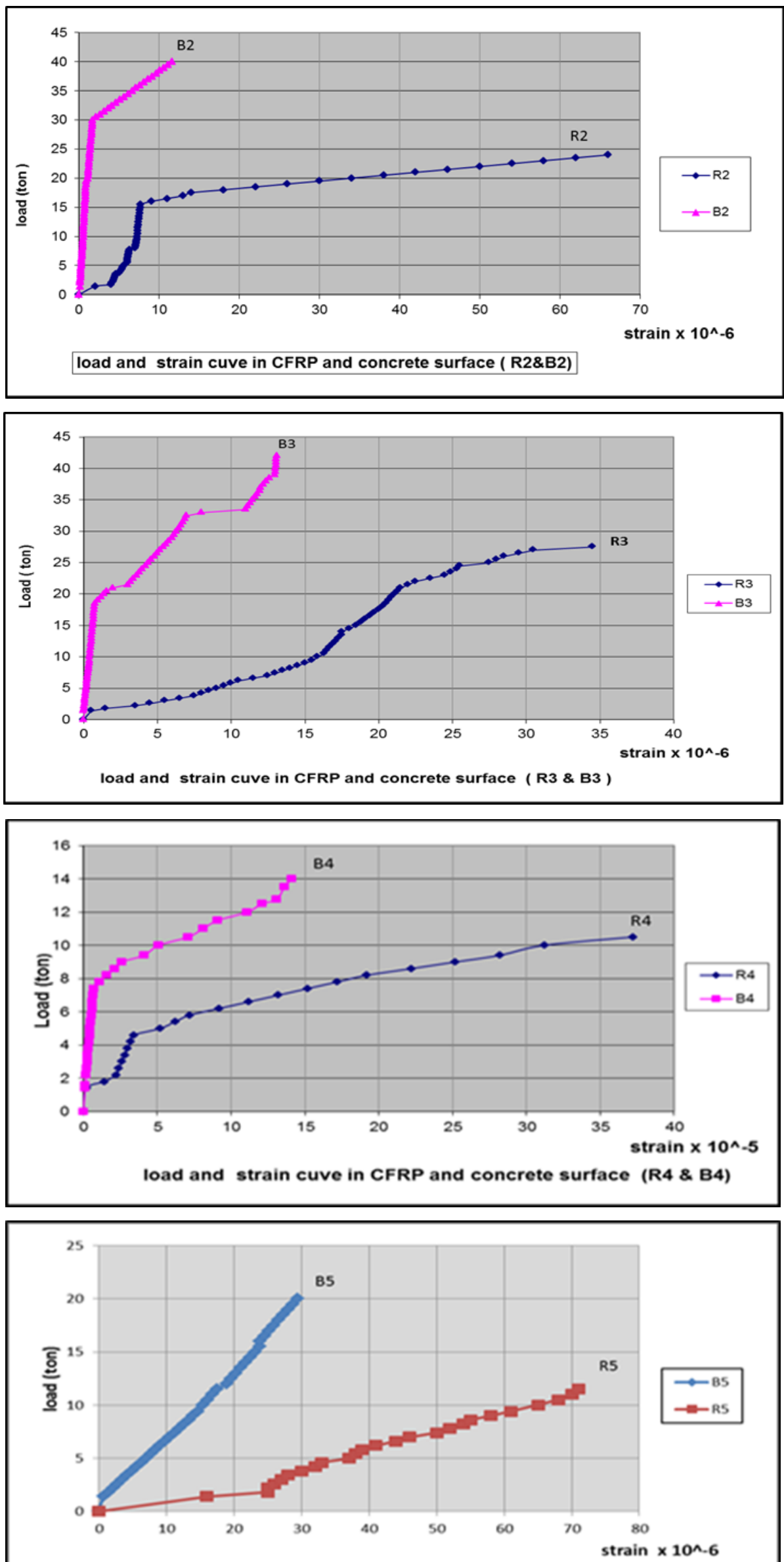

load and strain cuve in CFRP and concrete surface (RS \& BS) 
Some Parameters Affecting the Behavior of Strengthening of Rectangular R.C. Beams Failed in Shear by Using C.F.R.P.
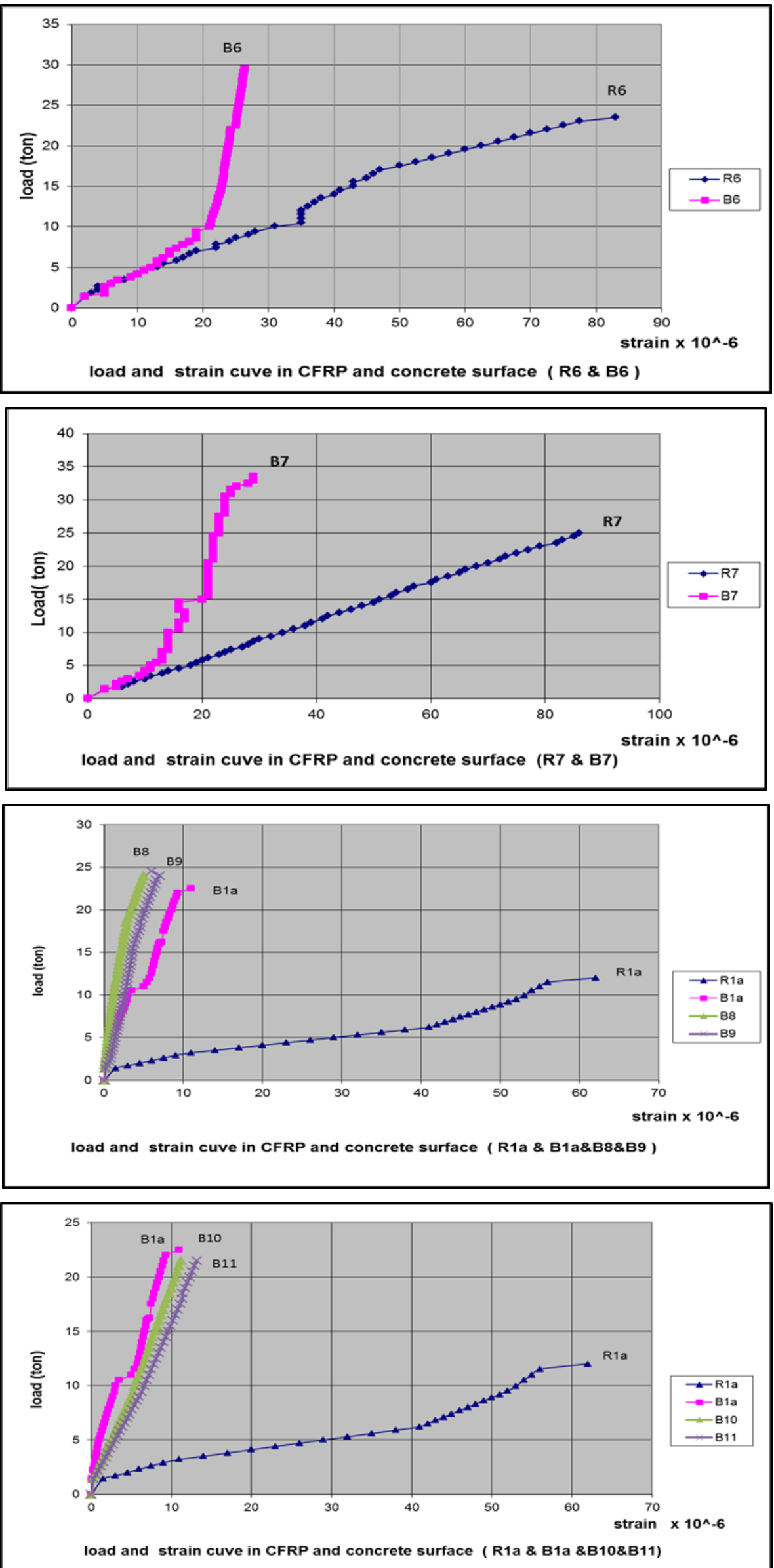


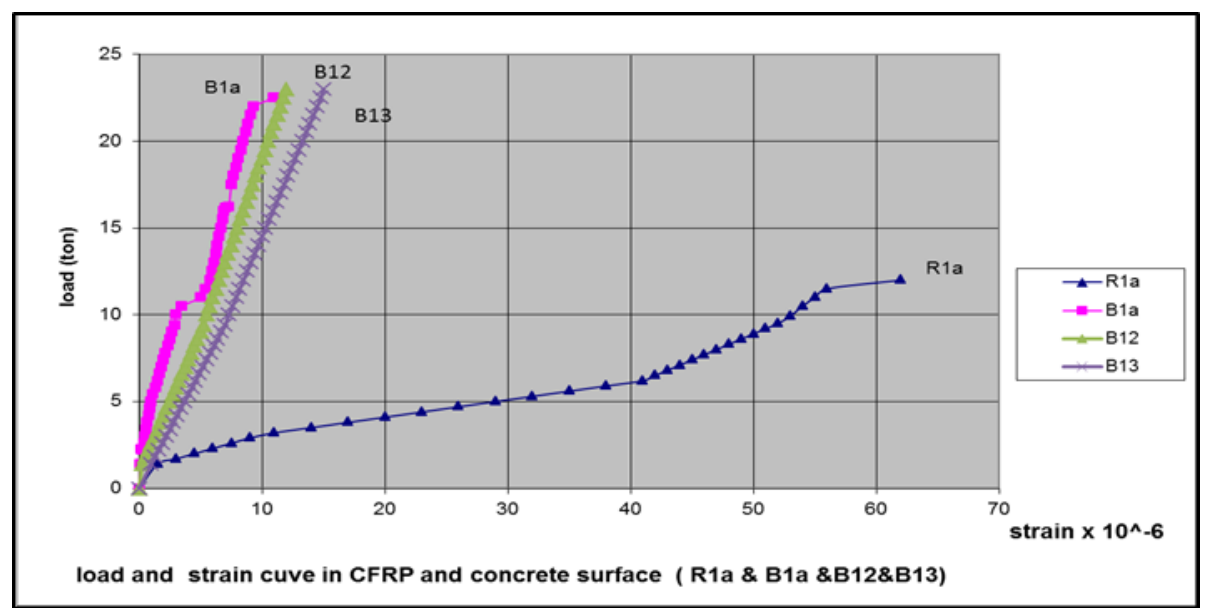

Fig4: Load and Strain curve in CFRP and concrete surface for test beams

\section{Discussion OF TEST RESUltS}

The previous obtained test results showed that the behavior of strengthened of reinforced rectangular concrete beams failed in shear basically affect the following properties:

i- Cracking load.

ii-Ultimate load capacity.

iii-Mode of beam failure.

iv-Ultimate deflection.

$\mathrm{v}$ - Ductility of beams.

vi-Ultimate concrete strain of beams.

vii- Toughness of beams.

\subsection{W.R.T Behavior of the Strengthened R.C. Rectangular Tested Beams}

In case of beams strengthened with CFRP-U-strips, diagonal crack was always followed by CFRP deponding and / or rupture, and failure occurred at a load significantly higher than for un-strengthened beam. The increase in failure load was ranged from $17 \%$ to $127 \%$ over than the control beam

Suchmainly previous properties are mainly affected by chosen parameters in this research as:

(i) Grade of concrete $\mathrm{Fc}_{28}$

ii) Longitudinal tensile reinforcement ratio $(\mu \%)$

(iii) \% of shear reinforcement

(iv) Orientation of CFRP strips $(\beta)$

(v) Width of CFRP strips $\left(\mathrm{W}_{\mathrm{f}}\right)$

(vi) Spacing of CFRP strips $\left(S_{f}\right)$

As follows:

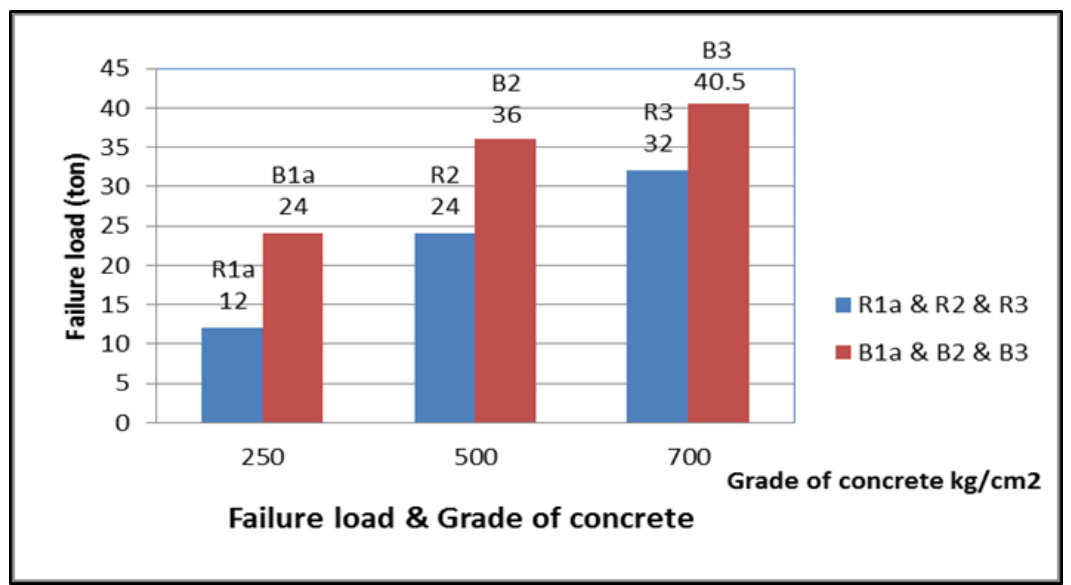


Some Parameters Affecting the Behavior of Strengthening of Rectangular R.C. Beams Failed in Shear by Using C.F.R.P.
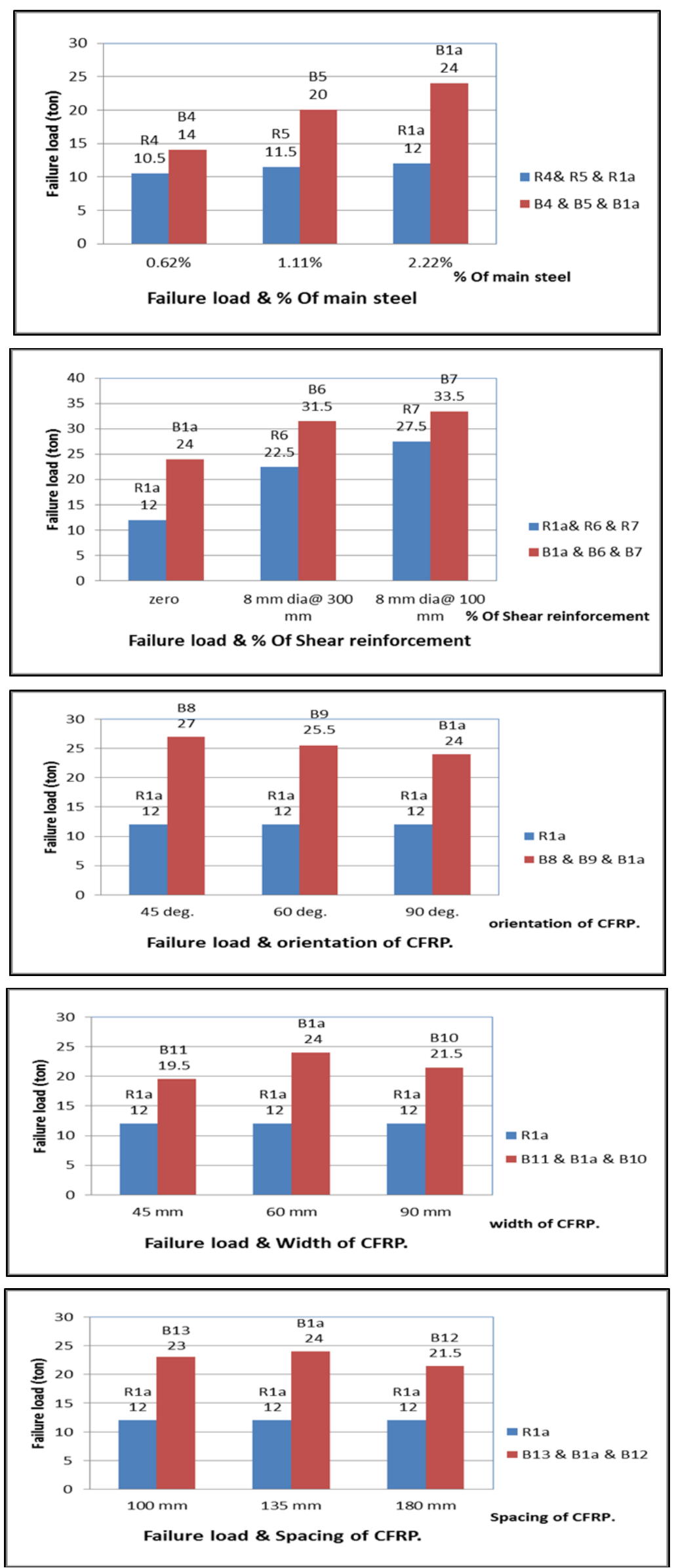

Fig5. Failure Load (Shear Capacity) for test beams 
Some Parameters Affecting the Behavior of Strengthening of Rectangular R.C. Beams Failed in Shear by Using C.F.R.P.

Table2: \% of shear enhancement for failure load

\begin{tabular}{|c|c|c|c|c|}
\hline $\begin{array}{l}\text { BEAM } \\
\text { NO. }\end{array}$ & $\begin{array}{l}\text { Failure load } \\
\text { (ton) }\end{array}$ & $\begin{array}{c}\text { Contribution of CFRP } \\
\text { strip(ton) }\end{array}$ & $\begin{array}{c}\% \text { of shear } \\
\text { enhancement }\end{array}$ & Mode of failure \\
\hline R1a & 12.00 & --------- & ------ & shear \\
\hline B1a & 24.00 & 12.00 & 100 & shear \\
\hline $\mathbf{R 2}$ & 24.00 & --------- & --------- & shear \\
\hline B2 & 36.00 & 12.00 & 50 & shear \\
\hline $\mathbf{R 3}$ & 32.00 & --------- & ------- & shear \\
\hline B3 & 40.50 & 8.50 & 26.56 & shear \\
\hline R4 & 10.50 & ------- & ------- & shear \\
\hline B4 & 14.00 & 3.50 & 33.33 & shear \\
\hline $\mathbf{R 5}$ & 11.50 & ------- & ------ & shear \\
\hline B5 & 20.00 & 8.50 & 73.91 & shear \\
\hline R6 & 22.50 & ------ & ----- & shear \\
\hline B6 & 31.50 & 9.00 & 40.00 & shear \\
\hline R7 & 27.50 & ------- & ------ & shear \\
\hline B7 & 33.50 & 6.00 & 21.82 & shear \\
\hline B8 & 27.00 & 15.00 & 125 & shear \\
\hline B9 & 25.50 & 13.50 & 112.5 & shear \\
\hline B10 & 21.5 & 9.50 & 79.20 & shear \\
\hline B11 & 19.5 & 7.50 & 62.50 & shear \\
\hline B12 & 21.50 & 9.50 & 79.20 & shear \\
\hline B13 & 23.00 & 11.00 & 91.70 & shear \\
\hline
\end{tabular}

Table 3: \% of shear enhancement for cracking load

\begin{tabular}{|c|c|c|c|c|}
\hline $\begin{array}{c}\text { BEAM } \\
\text { NO. }\end{array}$ & $\begin{array}{l}\mathbf{P}_{\text {crack }} \\
\text { (ton) }\end{array}$ & $\begin{array}{c}\text { Contribution of CFRP } \\
\text { strip(ton) } \\
\text { increasing cracking } \\
\text { load }\end{array}$ & $\begin{array}{c}\% \text { of shear } \\
\text { enhancement } \\
\text { increasing cracking } \\
\text { load }\end{array}$ & Mode of failure \\
\hline R1a & 6.60 & ----------- & ----------- & shear \\
\hline B1a & 11.50 & 4.90 & $74.24 \%$ & shear \\
\hline $\mathbf{R 2}$ & 13.50 & ----------.- & ----------.- & shear \\
\hline B2 & 16.50 & 3.00 & $22.20 \%$ & shear \\
\hline $\mathbf{R 3}$ & 14.50 & -----------. & ----------- & shear \\
\hline B3 & 17.00 & 2.50 & $17.24 \%$ & shear \\
\hline R4 & 5.00 & ---------.- & ---------.- & shear \\
\hline B4 & 7.40 & 2.40 & $48 \%$ & shear \\
\hline R5 & 5.40 & ---------- & 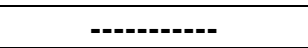 & shear \\
\hline B5 & 8.20 & 2.80 & $51.8 \%$ & shear \\
\hline R6 & 8.20 & ----------" & ----------- & shear \\
\hline B6 & 12.50 & 4.30 & $52.43 \%$ & shear \\
\hline $\mathbf{R 7}$ & 9.40 & ----------- & ----------- & shear \\
\hline B7 & 13.50 & 4.10 & $43.62 \%$ & shear \\
\hline B8 & 15.00 & 8.40 & $127.27 \%$ & shear \\
\hline B9 & 13.00 & 6.40 & $96.96 \%$ & shear \\
\hline B10 & 12.00 & 5.40 & $81.82 \%$ & shear \\
\hline B11 & $\mathbf{1 0 . 5 0}$ & 3.90 & $59.10 \%$ & shear \\
\hline B12 & 10.00 & 3.40 & $51.51 \%$ & shear \\
\hline B13 & 10.50 & 3.90 & $59.10 \%$ & shear \\
\hline
\end{tabular}

\subsubsection{W.R.Tgrade of Concrete $F c_{28}$}

The first crack for beams (B1a, B2 and B3) was observed in the region of center at middle third of the shear span between strips at load higher than those for control beams R1a, R2 and R3. The increase in cracking loads for these beams were $74.20 \%, 22.20 \%$ and $17.24 \%$, respectively with observed shear cracks initiated at higher levels of loads and cut for middle strip CFRP for beams B2 and B3. The failure loads of these beams are bigger than those of the control beams R1a, R2 and R3 by ratio100\%, $50 \%$ and $26.56 \%$, respectively. By using CFRP for these beams increase toughness and decrease ductility. These beams were failed in shear due to the major shear crack; Fig 2indicates the modes of failure for these beams. 


\subsubsection{W.R.T Longitudinal Tensile Reinforcement Ratio( $\mu \%)$}

The first crack for beams (B4, B5 and B1a) was observed in the region of center at middle third of the shear span between strips at load higher than those for control beams R4, R5 and R1a. The increase in cracking loads for these beams were $48 \%, 51.8 \%$ and $74.24 \%$ respectively with observed shear cracks initiated at higher levels of loads, which could across the middle strip for beams R5 and failure in compression zone for B4 Increasing the applied load, the secondary flexural crack increases toward the point of load. The failure loads of these beams are bigger than those of the control beams R4, R5 and R1a by ratio $33.33 \%, 73.91 \%$ and $100 \%$ respectively. By using CFRP for these beams increase toughness and decrease ductility, These beams were failed in shear due to the major shear crack; Fig 2 indicates the modes of failure for these beams.

\subsubsection{W.R.T \% of shear reinforcement}

The first crack for beams (B1a, B6 and B7) was observed in the region of center at middle third of the shear span between strips at load higher than those for control beams R1a, R6 and R7. The increase in cracking loads for these beams were $74.24 \%, 52.43 \%$ and $43.62 \%$, respectively with observed shear cracks initiated at higher levels of loads with split CFRP strip for beam B6 and cutting CFRP strip for beam B7, , the secondary flexural crack increases toward the point of load. The failure loads of these beams are bigger than those of the control beams R1a, R6 and R7 by ratio100\%, 40\% and $21.82 \%$, respectively. By using CFRP for these beams increase toughness and decrease ductility, These beams were failed in shear due to the major shear crack; Fig 2 indicates the modes of failure for these beams.

\subsubsection{W.R.T Orientation of CFRP strips}

The first crack for beams (B1a, B8 and B9) was observed in the region of center at middle third of the shear span between strips at load higher than those for control beam R1a. The increase in cracking loads for these beams were $74.24 \%, 127.27 \%$ and $96.96 \%$, respectively with observed shear cracks initiated at higher levels of loads with split CFRP strip for beam B8. The failure loads of these beams are bigger than those of the control beam R1a by $100 \%, 125 \%$ and $112.5 \%$, respectively. By using CFRP for these beams increase toughness and decrease ductility, These beams were failed in shear due to the major shear crack; Fig 2 indicates the modes of failure for these beams.

\subsubsection{W.R.T Width of CFRP strips}

The first crack for beams (B1a, B10 and B11) was observed in the region of center at middle third of the shear span between strips at load higher than those for control beam R1a. The increase in cracking loads for these beams were $74.24 \%, 81.82 \%$ and $59.10 \%$, respectively with observed shear cracks initiated at higher levels of loads at the shear span near the support, with split CFRP strip for beam B10 and B11. Increasing the applied load, the secondary flexural crack increases toward the point of load. The failure loads of these beams are bigger than those of the control beam R1a by $100 \%$, $79.20 \%$ and $62.50 \%$, respectively. By using CFRP for these beams increase toughness and decrease ductility, These beams were failed in shear due to the major shear crack; Fig 2 indicates the modes of failure for these beams.

\subsubsection{W.R.T Spacing of CFRP strips}

The first crack for beams (B1a, B12 and B13) was observed in the region of center at middle third of the shear span between strips at load higher than those for control beam R1a. The increase in cracking loads for these beams were $74.24 \%, 51.51 \%$ and $59.10 \%$, respectively with observed shear cracks initiated at higher levels of loads at the shear span near the support, with split CFRP strip for beam B12 and concrete crushing for beam B13. Increasing the applied load, the secondary flexural crack increases toward the point of load. The failure loads of these beams are bigger than those of the control beam R1a by $100 \%, 79.20 \%$ and $91.70 \%$, respectively. By using CFRP for these beams increase toughness and decrease ductility, These beams were failed in shear due to the major shear crack; Fig 2 indicates the modes of failure for these beams.

\subsection{Evaluation of the Shear Capacity of the CFRP Strengthened Beam}

In customary shear design approach, the shear strength of a reinforced concrete section may be computed by adding the contribution of shear strength of the concrete and steel reinforcement. But in 
the case of beam with externally bonded FRB sheets the nominal, shear strength may be formulated by the addition of a third component to account for the contribution, of FRP sheet to the Shear strength. For RC beam strengthened, with, externally bond composite, material, the nominal-shear, strength of the externally strengthened concrete section is expressed as follows:

$\mathrm{V}_{\mathrm{n}}=\mathrm{V}_{\mathrm{c}}+\mathrm{V}_{\mathrm{s}}+\mathrm{V}_{\mathrm{f}}$

In 2003, the ACI committee 440 proposed FRP contribution to shear strength of the FRP bonded beams. The shear contribution of the FRR shear rein for cement can be computed by the following equation:

$V_{f}=\frac{A_{f} f_{f e}(\sin \beta+\cos \beta) d_{f}}{S_{f}}$

In this equation, the component tensile stress in the FRP reinforcement at ultimate is replaced by effective strain times the tensile' modulus of $\mathrm{FRP} E_{f}$

$f_{f e}=\varepsilon_{f e} E_{f}$

The effective strain $\varepsilon_{\mathrm{fe}}$ is the maximum strain that can be achieved in the FRP system at the ultimate load and is governed by the failure pattern of FRP strengthened beam. . The subsequent equations provide direction to determine the effective strain $\varepsilon_{\mathrm{fe}}$ for different configuration of FRP wrap used for shear strengthening of reinforced concrete members

$\varepsilon_{f e}=0.004 \leq 0.75 \varepsilon_{f u}$ (for completely wrapped members)

$\varepsilon_{f e}=k_{v} \varepsilon_{f u} \leq 0.004$ (for bonded U-wraps or bonded face plies)

The bond reduction coefficient $k_{v}$ is a function of the concrete strength, the type of wrapping scheme used, and the '"stiffness of the wrap. The bond reduction coefficient can be computed as follows:

$k_{v}=\frac{k_{1} k_{2} L_{e}}{11.900 \varepsilon_{f u}} \leq 0.75$

The active bond length $L_{e}$ is the length over which the majority of the bond stress is maintained. The length is given by equation

$L_{e}=\frac{23,300}{\left(n t_{f} E_{f}\right)^{0.58}}$

The bond reduction coefficient also relies on two modification factors, $k_{1}$ and $k_{2}$, that accounts for the concrete strength and the type of wrapping scheme used respectively. Expressions for these modification factors are given as follows.

$k_{1}=\left(\frac{f_{c}^{\prime}}{27}\right)^{\frac{2}{3}}$

$k_{2}=\frac{d_{f}-L_{e}}{d_{f}}$

(For U-wraps)

$k_{2}=\frac{d_{f}-2 L_{e}}{d_{f}}$

(For two sides bonded)

The comparison of experimental and theoretical results of the control and initially strengthened beams are shown in Table 4. It can be seen that the experimental values of the strengthened beams $\mathrm{B} 1 \mathrm{a}, \mathrm{B} 2, \mathrm{~B} 3, \mathrm{~B} 4, \mathrm{~B} 5, \mathrm{~B} 6, \mathrm{~B} 7, \mathrm{~B} 8, \mathrm{~B} 9, \mathrm{~B} 10, \mathrm{~B} 11, \mathrm{~B} 12$ and B13were relatively greater than theoretical values by ( 0.0 to $130 \%)$.From the overall discussion, it can be concluded that the predicted theoretical results of the rectangular beam without internal shear reinforcement but with external CFRP shows reasonable accuracy with the experimental results.

Table4: Summary of comparison of experimental and theoretical results

\begin{tabular}{|c|c|c|c|c|c|c|}
\hline \multicolumn{3}{|c|}{ Experimental results } & \multicolumn{4}{|c|}{ Theoretical results (ACI 440 format) } \\
\hline $\begin{array}{l}\text { BEAM } \\
\text { NO. }\end{array}$ & $\begin{array}{c}\text { Failure } \\
\text { load (ton) }\end{array}$ & $\begin{array}{c}\text { Shear force } \\
\text { (ton) }\end{array}$ & $\begin{array}{c}V_{c} \\
\text { (ton) }\end{array}$ & $\begin{array}{c}V_{s} \\
\text { (ton) }\end{array}$ & $\begin{array}{c}V_{f} \\
\text { (ton) }\end{array}$ & $\begin{aligned} V_{n}= & V_{c}+V_{s+} V_{f} \\
& \text { (ton) }\end{aligned}$ \\
\hline R1a & 12.00 & 6.00 & 3.80 & $\begin{array}{ll}--- \\
-\end{array}$ & ---- & 3.80 \\
\hline B1a & 24.00 & 12.00 & 3.80 & $-\cdots$ & 3.40 & 7.20 \\
\hline
\end{tabular}


Some Parameters Affecting the Behavior of Strengthening of Rectangular R.C. Beams Failed in Shear by Using C.F.R.P.

\begin{tabular}{|c|c|c|c|c|c|c|}
\hline $\mathbf{R 2}$ & 24.00 & 12.00 & 5.20 & ---- & ---- & 5.20 \\
\hline B2 & 36.00 & 18.00 & 5.20 & -.--- & 3.40 & 8.60 \\
\hline R3 & 32.00 & 16.00 & 6.20 & ---- & ---- & 6.20 \\
\hline B3 & 40.50 & 20.25 & 6.20 & ------ & 3.40 & 9.60 \\
\hline R4 & 10.50 & 5.25 & 3.80 & ---- & ---- & 3.80 \\
\hline B4 & 14.00 & 7.00 & 3.80 & ---- & 3.40 & 7.20 \\
\hline R5 & 11.50 & 5.75 & 3.80 & ----- & ---- & 3.80 \\
\hline B5 & 20.00 & 10.00 & 3.80 & --- & 3.40 & 7.20 \\
\hline R6 & 22.50 & 11.25 & 3.80 & 4.30 & ---- & 8.10 \\
\hline B6 & 31.50 & 15.75 & 3.80 & 4.30 & 3.40 & 11.50 \\
\hline R7 & 27.50 & 13.75 & 3.80 & 6.20 & ---- & 10.0 \\
\hline B7 & 33.50 & 16.75 & 3.80 & 6.20 & 3.40 & 13.40 \\
\hline B8 & 27.00 & 13.50 & 3.80 & ------ & 4.40 & 8.20 \\
\hline B9 & 25.50 & 12.75 & 3.80 & ------ & 4.20 & 8.00 \\
\hline B10 & 21.5 & 10.75 & 3.80 & ------- & 4.90 & 8.70 \\
\hline B11 & 19.5 & 9.75 & 3.80 & --.---. & 2.90 & 6.70 \\
\hline B12 & 21.50 & 10.75 & 3.80 & ------- & 2.95 & 6.75 \\
\hline B13 & 23.00 & 11.50 & 3.80 & ----- & 4.10 & 7.90 \\
\hline
\end{tabular}

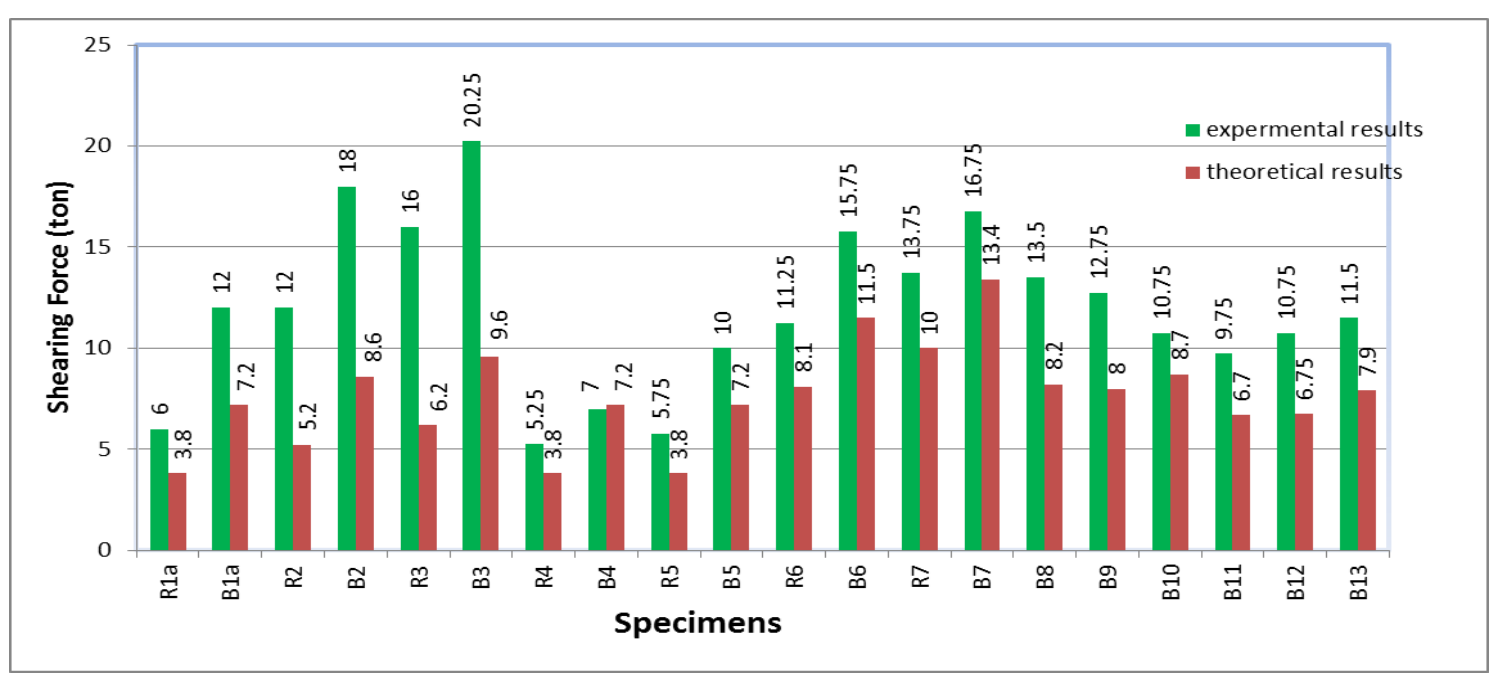

Fig6. Comparison of experimental results with theoretical values of controlled and strengthened beams

\section{CONCLUSiOnS}

This paper presents the experimental results of R-beams bonded externally with CFRP fabric strips. Following conclusions are deduced from the experimental investigation:

1. Experimental results have shown that the overall increase in shear strength of the CFRP strengthened beams ranged between $17 \%$ and $127 \%$ over the control beam. From this result, it was concluded that the externally bonded CFRP strip technique significantly increase the shear strength of RC beams with internal steel stirrups

2. Increasing grade of concrete increases the ultimate shear capacity of the strengthened beam of (efficiency) CFRP.

3. Increasing the longitudinal reinforcement ratio by $100 \%$ increases the ultimate shear capacity of the strengthened beam up to $20 \%$.

4. The shear capacity of the external bonded CFRP rectangular beams without internal shear reinforcement shows reasonable efficiency more than rectangular beams with internal shear reinforcement.

5. Experimental results indicate that the specimen with $45 / 135$ degree inclined L-CFRP strips gained better enhancement of $16 \%$ greater than the vertical CFRP U-strips, With decreasing the angle of inclination from $90^{\circ}$ to $45^{\circ}$, the shear strength increases till reaching the optimum angle of inclination of $45^{\circ}$. 
6. Increasing the number of the bonded laminates enhances generally the behavior of the beam leading to an increase in both cracking and ultimate shearing loads; meanwhile it decreases the induced deformation and achieving a brittle mode of failure.

7. It was found that increasing the spacing of CFRP strip reinforcement by $33 \%$ decreases the shear capacity of the strengthened beam to $17 \%$.

8. After repair with CFRP laminates, an enhancement in crack behavior of the original beams was achieved in general for different used schemes.

9. Using the CFRP laminates decreases width, length and the propagation of the original shear cracks, which appeared in the preloading stage in the critical shear zone.

10. Increasing the spacing between the laminates till reaching $0.5 \mathrm{~d}$ (the best spacing), improves the behavior of the tested beams in controlling the shear cracks and increases the resistance of the cross section to the external loads with decreasing the accompanied measured deformations.

11. using CFRP strips increase toughness and decrease ductility of beams.

\section{RECOMMENDATIONS}

From the pre-described analysis for the test results and the above conclusions, it is recommended for the future research work the following topics:

1. The effect of the CFRP technique for both repairing and strengthening for reinforced concrete beams having T-section

2. The behavior of reinforced concrete beams strengthened with various advanced composite materials under dynamic and repeated loads.

3. The effect of chemical attack on the CFRP strengthening system for reinforced concrete elements.

4. The effect of high degree of temperature (fire resistance) on the CFRP strengthening system for reinforced concrete elements.

5. Theoretical analysis for modeling of reinforced concrete elements combining concrete, steel reinforcement and CFRP laminates.

6. The behavior of heavily damaged reinforced concrete beams strengthened with various advanced composite materials

7. The behavior of over reinforced concrete beams strengthened with various advanced composite materials

\begin{tabular}{|c|c|c|c|}
\hline \multicolumn{4}{|c|}{ Nomenclature } \\
\hline$A_{f}$ & $2 n t_{f} w_{f}$ & $n$ & number of FRP plies or layers \\
\hline $\mathrm{b}_{w}$ & width of beam & $t_{f}$ & thickness of FRP \\
\hline $\mathrm{d}_{f}$ & $\begin{array}{l}\text { effective depth of FRP fabric equal } \\
\text { to the effective }\end{array}$ & $s_{f}$ & spacing of FRP fabric strips \\
\hline $\mathrm{E}_{f}$ & tensile modulus of FRP & $w_{f}$ & width of FRP fabric strips \\
\hline$f_{c}^{\prime}$ & $\begin{array}{l}\text { compressive strength of concrete } \\
\text { cylinder }\end{array}$ & $v_{c}$ & nominal shear strength contributed by concrete \\
\hline$f_{\mathrm{fe}}$ & tensile stress in FRP at ultimate & $v_{s}$ & nominal shear strength contributed by steel \\
\hline $\mathrm{k}_{v}$ & bond reduction coefficient & $v_{f}$ & nominal shear strength contributed by FRP \\
\hline $\mathrm{K}_{1}$ & $\begin{array}{l}\text { bond reduction coefficient for } \\
\text { concrete strength }\end{array}$ & $\varepsilon_{f e}$ & effective FRP strain \\
\hline $\mathrm{K}_{2}$ & $\begin{array}{l}\text { bond reduction coefficient for } \\
\text { wrapping scheme }\end{array}$ & $\varepsilon_{f u}$ & ultimate FRP strain \\
\hline $\mathrm{L}_{\mathrm{e}}$ & active bond length & $\beta$ & $\begin{array}{l}\text { angle between the principle fiber orientation and the } \\
\text { longitudinal axis of the beam }\end{array}$ \\
\hline$\varepsilon_{c}$ & Strain of concrete surface & $\mu \%$ & Longitudinal tensile reinforcement ratio \\
\hline$\varepsilon_{S}$ & $\begin{array}{l}\text { Strain of longitudinal tensile } \\
\text { reinforcement }\end{array}$ & $\delta_{u}$ & Max mid-span deflection at failure load \\
\hline$f_{c 28}$ & $\begin{array}{l}\text { compressive strength of concrete } \\
\text { cube } 15^{*} 15^{*} 15 \text { after } 28 \text { days }\end{array}$ & $\delta_{c r}$ & Mid-span deflection at cracking load \\
\hline
\end{tabular}




\section{REFERENCES}

[1] ACI Committee 318. (2011). "Building code requirements for reinforced concrete." (ACI 318-11), American Concrete Institute, Farmington Hills, MI, USA.

[2] Altun, F. (2004). An Experimental Study of the Jacketed Reinforced Concrete Beams under Bending. \& quot; Construction and Building Materials, 18, 611-618.

[3] Amani, J., and Moeini, R. (2012), Prediction of Shear Strength of Reinforced Concrete Beams Using Adaptive Neuro-Fuzzy Inference System and Artificial Neural Network. Scientia Iranica, 19(2), 242-248.

[4] Araújo, D. D. L., Nunes, F. G. T., Toledo Filho, R. D., and Andrade, M. A. S. de. (2014), Shear Strength of Steel Fiber-Reinforced Concrete Beams. Acta Scientiarum. Technology, 36 (3), 389-397.

[5] ASTM C1611/C1611M - 14. (2014). Standard Test Method for Slump Flow of Self- Consolidating Concrete. ASTM International, West Conshohocken, PA, USA.

[6] Awad, K. A. (2009). "Requirements of Shear and Flexural Reinforcement of High Strength Concrete Beams.”. M.Sc. Thesis, Assiut University, Assiut, Egypt.

[7] Cuenca, E., and Serna, P. (2013), Shear Behavior of Prestressed Precast Beams Made of Self-Compacting Fiber Reinforced Concrete. Construction and Building Materials, 45, 145-156.

[8] Cunha, V. M. C. F., Barros, J. A. O. and Sena-Cruz, J. M. (2010). Tensile Behavior of Steel FiberReinforced Self-Compacting Concrete. ACI Symposium Publications, research and application, FiberReinforced Self- Consolidating Concrete: research and applications, SP-274, Aldea, C. and Ferrara, L., Eds., American Concrete Institute, Farmington Hills, MI, USA

[9] Ding, Y., You, Z. and Jalali, S. The Composite Effect of Steel Fibers and Stirrups on the Shear Behaviour of Beams Using Self-Consolidating Concrete. Engineering Structures, 33(1),107-117.

[10] Nili, M. and Afroughsabet, V. (2010). Combined Effect of Silica Fume and Steel Fibers on the Impact Resistance and Mechanical Properties of Concrete. International Journal of Impact Engineering, 37(8), 879-886.

[11] ECP committee 203. (2007). "The Egyptian Code for Design and Construction of Concrete Structures", Housing and building research center, Giza, Egypt.

[12] Khalaf, Q. (2015). Comparative Study for Strengthening Techniques of RC Beams Using Concrete Jackets and Steel Plates. M.Sc. Thesis, Islamic University of Gaza, Gaza, Palestine.

[13] Khayat, K. H. and Roussel, Y. (2000). Testing and Performance of Fiber- Reinforced Self- Consolidating Concrete. Materials and Structures, 33(6), 391-397.

Citation: Dr. Assem Nan Saleeb Kaldes, et.al. (2018) "Some Parameters Affecting the Behavior of Strengthening of Rectangular R.C. Beams Failed in Shear by Using C.F.R.P.", International Journal of Constructive Research in Civil Engineering, 4(1), pp.49-69. DOI: http://dx.doi. org/10.20431/24548693.0401006

Copyright: $\odot 2018$ Dr. Assem Nan Saleeb Kaldes, This is an open-access article distributed under the terms of the Creative Commons Attribution License, which permits unrestricted use, distribution, and reproduction in any medium, provided the original author and source are credited. 